\title{
POSITION
}

\section{NÅR STEMMERNE FORSTUMMER}

Om samarbejde, vidensdeling og forræderi

\author{
PERLE MØHL OG ANJA SIMONSEN
}

I det kollaborative forskningsprojekt „Biometric Border Worlds“ udforsker vi biometriske teknologiers ${ }^{1}$ epistemiske grundlag, udvikling og anvendelse i forbindelse med migration ind i og igennem Europa. Vi undersøger samtidig migranters deltagelse i udviklingen af teknologierne igennem deres specialiserede kendskab til og undvigelser af de forskellige anvendte teknologier.

Biometriske teknologier anvendes til at installere fysiske grænser og begrænsninger af bevægelse mellem nationer ved konkrete grænseposter. Derudover skaber teknologierne immaterielle grænser ved at give eller formene adgang til $\mathrm{fx}$ mobiltelefoner og kontorer, og når de anvendes til visumafgørelser og familiesammenføringer i konsulater og lufthavne i lande langt fra Europas grænser. Biometriske teknologier udfører bestemte, algoritmisk determinerede koblinger mellem biologiske træk - fx dna, ansigtsform, fingeraftryk, irisform, venetegninger, gangart - og id-information lagret i databaser. Sådanne koblinger er ikke utvetydige og naturlige, men udspringer af og er indlejrede i sociale, politiske og juridiske forordninger og ideer om migration, kriminalitet og grænsekontrol samt i bestemte ideer om forholdet mellem krop, billeder og identitet.

Forskningsprojektet består af fire underprojekter, som hver især anskuer og udforsker grænseverdener fra forskellige og ofte kontrasterende perspektiver, og som forfølger forbindelser mellem feltets mange forskelligartede aktører. Anjas underprojekt omhandler således somaliske kvinder og mænds oplevelser af, erfaringer med og praksisser med biometriske teknologier såsom fingeraftryk og identitetsbilleder i en migrationskontekst. Anja har udført feltarbejde siden 2013 blandt somaliske kvinder og mænd på flugt og har arbejdet i henholdsvis Somaliland, Tyrkiet, Grækenland og Italien. Perles underprojekt omhandler politi og grænsevagters brug af biometriske teknologier såsom ansigtsgenkendelse, x-ray-scannere, infrarøde sensorer og droner i deres daglige grænsebevogtning samt helt fundamentalt, hvordan grænsevagter laerer at se, både direkte og via teknologi- 
ernes visuelle interfaces. Perles analyser er baseret på feltarbejder i Københavns Lufthavn, Gibraltar og Ceuta, spansk enklave i det nordlige Marokko.

I vores projekt har vi således hver især placeret os i ret forskellige og konfliktuerende „lejre“ $i$ dette højspændte felt, som krydsningen mellem biometriske teknologier og migration udgør.

På baggrund af foreløbig halvandet års samarbejde stiller vi os selv nogle fundamentale etiske og epistemologiske spørgsmål om grundvilkårene for dette samarbejde - spørgsmål, som vi arbejder på en længere artikel om, og som vi gerne vil præsentere nogle af de indledende momenter af her. De handler på den ene side om konsekvenserne af at samarbejde og dele viden i et spændingsladet politisk felt uden at give køb på de hensyn og loyaliteter, vi hver især har til vores respektive felter, og på den anden side spørger vi, om det er rimeligt at antage, at vi kan føle samme form for loyalitet og ansvar over for forskellige grupper, som indgår i et skævt magtforhold. Vi tager kun toppen af isbjerget her som en slags smagsprøve på en række spændende fundamentale spørgsmål, som vores særlige projektdesign, forskningstematikker og arbejdsdeling har givet anledning til. Således spørger vi os selv og hinanden:

1) Kan vi samarbejde og dele viden om et sådant spændingsladet politisk felt uden at begå forræderi mod vores respektive samarbejdspartnere i felten? Hvis ikke, hvor efterlader det os så i forhold til etnografi baseret på samarbejde og på sammenstykning af meget forskellige typer elementer fra forskellige kontekster (assemblageetnografi)? Eller, med andre ord, kan vi forestille os et samarbejde, hvor viden ikke deles? Og hvad vil ligge til grund for de respektive grader af ,åbenhed“ og deling?

2) Er der nogle informanter, der i højere grad end andre fortjener vores loyalitet? Hvis ikke, hvordan konfigurerer det helt fundamentalt vores position og erfaring, de indsigter, vi tillader os selv at få i felten, og den viden, vi producerer? Og hvis vi vender perspektivet på hovedet, hvad kan vi så lære af disse overvejelser om de loyaliteter, som vi normalt tager for givet?

\section{Frokost og selektiv loyalitet - når viden ikke bare kan deles}

Vi beskriver nu to konkrete cases. I vores analyse bliver de imidlertid til én case, netop fordi de støder imod hinanden og skaber friktion og dermed afstedkommer en serie etiske diskussioner imellem os, blandt andet om det at dele viden. At de støder imod hinanden, skyldes vores projektdesign, vores kollaborative „assemblageetnografi“", hvor hele grundfilosofien er, at vi hver især vil kunne udforske forskellige sider af den biometriske grcenseverden og løbende vil kunne sammenstykke vores forskellige vidensfelter og perspektiver til ét samlet billede. 
Den grundtanke rystes pludselig og giver plads for en serie fundamentale etiske overvejelser, som vi måske aldrig rigtig vil finde en løsning på. De er ikke paradokser, men snarere uforeneligheder eller flugtlinjer, som ikke mødes.

Vi sidder og spiser frokost sammen, som så ofte før, og udveksler erfaringer fra vores igangværende feltarbejder. Perle fortæller noget, hun har hørt hos grænsepolitiet i lufthavnen. Om sokker. Anja kigger op, vores blikke mødes, og vi indser i samme øjeblik, at nogle meget væsentlige spørgsmål om viden og om vidensdeling er ved at udspille sig her, hen over vores kollegiale frokost. Det er spørgsmål, som vi begge i dette øjeblik bliver bevidste om, at vi vil skulle gennemtænke grundigt, og som vi med al sandsynlighed ikke vil kunne besvare endeligt.

\section{Ankomster}

Københavns Lufthavn, Schengen-paskontrol, „lokalbanen“: Et lavprisfly er netop ankommet fra Sabiha Gökçen i Tyrkiet. Johnna gør sig klar i sin boks, hvor hun den næste times tid skal kontrollere pas, visa og fingeraftryk på de ankommende passagerer. Tyrkiet er defineret som „højrisiko“ og kræver særlig opmærksomhed. Johnna har hævet sit bord, så hun kan stå op ,for bedre udsyn“. Passagererne bevæger sig ind i kontrolzonen. Det er en blanding af hjemvendte danske turister, nogle af tyrkisk oprindelse, af tyrkiske besøgende og af andre statsborgere, hovedsageligt fra Mellemøsten, Sydasien og Østafrika. Johnna råder over en passcanner forbundet til en række internationale databaser, en fingeraftryksscanner til visumkontrol, en uv-scanner til dokumentfalskkontrol og en gammeldags højdemåler til at sammenholde den rejsendes højde med oplysningerne i passet. Derudover har hun sine øjne, ører, næse, fingre og sin sjette sans, som hun siger.

Hun ser ud på køerne, der har dannet sig foran de tre åbne bokse. Hun holder øje med, om der er nogen, der pludselig skifter kø. „Nogle gange, hvis de har noget at skjule, tror de, min kollega derovre er rarere eller mindre opmærksom. Det er han ikke." Hun tjekker, hvem der taler sammen og måske rejser sammen. Hun ser efter, om nogen sveder eller ser nervøse ud eller på anden vis afviger fra det normale. Samtidig kontrollerer hun dokumenter, sammenligner billeder med ansigter, spørger om folks rejseplaner, tjekker, om de har været her før, og hvornår deres billet er købt, og visum er blevet udstedt. Hun beder om returbilletter, spørger om indkvartering og årsagen til deres besøg og spørger, hvem de rejser med. Hun scanner pas og visa og beder folk om at stille sig ved højdemåleren eller lægge deres højre pegefinger på fingeraftryksscanneren. Det scannede visum springer op på skærmen, kontrolleres i VIS-databasen, og et grønt $\sqrt{ }$ angiver, at fingeraftrykket er o.k. Imens teknologien arbejder, sludrer Johnna med 
de rejsende, afstemmer deres historier med de andre oplysninger, hun har, alt mens hendes blik scanner ned, op, ud - ned, op, ud - ned på dokumenterne og skærmene, $o p$ på ansigterne og $u d$ på menneskene i køerne. Hun lytter til maskinernes bippen, ser på folks tøj og håndtasker, lytter til deres sprogfærdigheder og accenter og verificerer, at alle de historier, hun hører, og de observationer, hun gør sig, stemmer overens. „Du kan altid genkende en ulovlig etiopier på tøjet. De har altid nye jakkesæt på, og hvis du løfter i ærmekanten, sidder prissedlen der stadig - hvis nu de nægtes adgang og skal returnere det. Og de har aldrig sokker på. Så du skal bare kigge ned og se efter, om de har bare fødder i deres fine sko." Hun ler ikke, er ikke skadefro. Hun gør bare sit arbejde, profilerer folk og aflurer deres fif og kneb, vaner og tendenser, kontrollerer historier og laver små fremtidsscenarier. Hun bruger sin akkumulerede erfaring og tilpasser den til de globale strømninger. Hun ved, at folk forsøger at komme igennem, og at de vil tage alle deres egne højtudviklede kompetencer og teknologier i brug. Hun ser sit job som en leg mellem kat og mus, hvor hendes opgave er at fokusere sin opmærksomhed, mens deres er at aflede den, og hvor hun aldrig rigtig ved, om hun er katten eller musen.

\section{Afrejser}

Riyaan og Anja finder ly for Sydeuropas varme temperaturer i Riyaans midlertidige hjem i Grækenland, et hjem, hun bebor sammen med en gruppe andre somaliske kvinder, mens de venter på at flygte fra Grækenland og videre ind i Europa. Riyaan er en somalisk kvinde sidst i 30'erne, som Anja mødte gennem sit feltarbejde blandt udokumenterede somaliske migranter, først i Tyrkiet og derefter i Grækenland. Det lyseblå værelse, som midlertidigt udgør Riyaans hjem, består af et stort skab og madrasser, der fylder rummets gulv, som Riyaan og de andre kvinder sover på om natten. Riyaan præsenterer Anja for de andre kvinder. I dag er de fleste kommet for at besøge en kvinde i huset, som er blevet syg under flugten - en kvinde, som Riyaan har et nært kendskab til. Mange af dem har opbygget nære relationer, enten fordi de er relateret gennem slægtskab, eller fordi de har knyttet tætte venskaber gennem de svære oplevelser, de har været igennem sammen, såsom fængsling. De taler meget hurtigt og på somalisk. Riyaan oversætter: „Alle leder efter et pas, hvor deres ansigt matcher det, der er i passet." At låne en anden kvindes pas, mod betaling, og dermed kunne gå om bord på et fly, er en af de sikreste måder at flygte på som kvinde, da det er der, du har den bedste chance for at undgå voldtægt - og det værst tænkelige - døden. Forskellige former for købte id-kort bliver cirkuleret blandt kvinderne i det lille værelse. En af dem løfter et id-kort op og spørger: „Er dette et pas?“ 
Alle griner, og Riyaan vender sig om til Anja og siger: „Hun tror, det er et pas, hun er dum." At rejse som illegal somalisk kvinde afhænger ikke kun af, hvor mange penge du har. Det kræver også en forståelse af dokumenter, hvilke de skal bruge, hvor og hvordan, hvis de skal være i stand til at flygte fra det, som mange af dem oplever som social død i Grækenland. Id-kortene, som cirkuleres, er blevet sendt til en af kvinderne fra hendes familiemedlemmer bosat i Europa. Hun har for nylig forsøgt at forlade Grækenland, men blev stoppet og nægtet afrejse. „De fortalte hende, at hendes ansigt ikke matchede det på passet, “ forklarer Riyaan og tilføjer, at hvis de rejser med en kvinde som Anja, vil det forøge chancen for en succesfuld afrejse. Anjas selskab vil tilføje et ekstra sidestykke til narrativet om den rejsende turist, som de håber at fremstille. En af de yngre kvinder i værelset vil forsøge at flygte i morgen om bord på et fly. Hun har netop sluttet sig til vores selskab efter at have været ude at købe nyt tøj - tøj, der på ingen måde ligner den lange, farverige sheet, som typisk bliver båret af somaliske kvinder. Tværtimod er det nyindkøbte tøj baseret på en idé om et vestligt look i håbet om at matche narrativet om en europæisk statsborger på ferie i Grækenland. Efter at have hilst på os alle forlader hun rummet igen. Kort efter kommer en anden ung somalisk kvinde ind iklædt bukser, en skjorte og en jakke. Anja hilser på hende med det sædvanlige: „Salaam caleikum.“ De andre kvinder griner. Det viser sig, at de griner af Anja. „Er det godt?“ spørger kvinden, som Anja netop har hilst på. Det går op for Anja, at kvinden er hende, som lige har været ude at købe nyt tøj. Anja kan ikke andet end svare „Ja, det er meget godt" til hendes spørgsmål, da hun netop har været en del af en test uden at vide det, en test, som alle håber vil gå netop, som den gjorde her, når de en dag forsøger at flygte videre mod Europa. Forberedelserne fortsætter for den unge kvinde med at lægge ansigtsmaske, at pakke færdig osv., mens vi sidder her i dette lille værelse på en varm sommerdag i Grækenland.

\section{Viden, positioner og overblik}

Frokosten er for længst overstået og fordøjet. Men de spørgsmål og tanker, som opstod hen over frokostbordet, er på ingen måde absorberet og glemt. Tværtimod fortsætter de med at perspektivere både vores individuelle arbejde i felten og vores fælles diskussioner.

På den ene side anerkender vi, at vores respektive indsigter i den biometriske grænseverden måske er ganske inkompatible eller endda taler forbi hinanden som flugtlinjer, der ikke krydser hinanden. Og af lige så stor relevans for diskussionen af etik og loyalitet er vores gensidige erkendelse af, at der er indsigter, som vi har opnået i felten ved at være engagerede og positionerede, og som vi ikke kan 
dele. For det første ville det at dele elementer af vores viden være et væsentligt brud på den loyalitet, som vi har til de mennesker, hvis liv og aktiviteter vi har engageret os i, mens vi var i felten. For det andet ville der i forsøget på at sammenstykke viden fra alle vores forskellige positioner til et helhedsbillede ligge en uerkendt tilstræbelse efter i fællesskab at opnå et slags umenneskeligt overblik, hvor vi som vidende subjekter netop fjernede os fra og bedrog selve den videns karakter som indlejret og levet. Det analytiske arbejde er måske nok at stræbe efter at forstå nogle større sammenhænge og at sammenligne, men altid på basis af levet fragmentarisk liv, som gerne skal bevare sin positionerethed i analysen og aldrig stræbe efter hverken helhed eller objektivitet. Men er vi - sammen med andre antropologer, som samarbejder, sammenstykker og laver assemblageetnografi - $\mathrm{i}$ bund og grund ude på at annullere og neutralisere det vidende subjekts partielle og positionerede perspektiv til fordel for en „højere“ holistisk vidensskabelse? Og, endelig, så har vi og vores „videnssammenstød“ fået os til at stille nogle ganske fundamentale spørgsmål om de loyaliteter, som vi opretholder over for mennesker i felten. Det har gjort os klart, at der er spørgsmål, som vi ofte glemmer at stille, men som de modstridende drømme, kræfter og flows, som er på spil i vores felt, imidlertid har bragt frem forrest på scenen, især fordi det blandt andet indebærer en loyalitet over for en ordensmagt. Dette fjerner ikke muligheden for kritik, tværtimod - kun ved et personligt, dagligt engagement kan vi overhovedet skabe grundlaget for at formulere en sådan kritik - men det fremhæver behovet for at tænke i og tale om, hvordan loyalitet spiller ind i vores vidensdannelse og i vores forhold til alle de forskelligartede mennesker og grupper, som vi arbejder sammen med i felten, og det personlige ansvar, vores viden giver os. Disse spørgsmål kræver om ikke svar og forløsning så i al fald vores fulde opmærksomhed.

Afsluttende vil vi gerne spinde nogle ender over begrebet loyalitet, hvad der sættes på spil i vores respektive felter, og om loyalitet er den rette term at bruge om de forskellige slags ,vidensansvar“, som vi måtte have i forhold til vores samarbejdspartnere i felten. Det gør vi ved hver især at spekulere over nogle af de dilemmaer, vi står over for i vores daglige arbejde i felten med de mennesker, som befolker den.

\section{Anja tænker ...}

Det er sidst på sommeren i Grækenland i 2014, og mit feltarbejde blandt somaliske kvinder og mænd en route lakker mod enden. Min kommende afrejse er omdrejningspunktet for den uformelle samtale, jeg har, mens jeg går i Athens gader med a) Mire, en somalisk mellemmand (på somalisk: muxalas) på den ene 
side, hvis formål med opholdet i Grækenland er at hjælpe andre somaliere videre mod resten af Europa, og b) Ladan, en ung somalisk kvinde, på den anden side, som har købt sig til Mires hjælp og står til at rejse i den kommende uge. Eller, det vil sige, det er, hvad han har fortalt Ladan, at hun skal. Men som jeg går her og informerer dem begge om min kommende afrejse tilbage til Danmark, siger Mire, på et sprog, som Ladan ikke mestrer, at han også rejser ud af Grækenland om et par dage. Denne information giver mig ubehag. Hvorfor fortæller han mig, at han rejser om et par dage, når Ladan netop har forklaret, at selvsamme mand står for hendes afrejse om en uge? En masse tanker om loyalitet og ansvar går igennem mig, mens jeg går her. Skal jeg tie og på den måde forholde mig „,objektivt" til min felt ved ikke at vælge side og på den måde undgå en gruppering af informanter i ,de gode“ og „,de onde“, „de magtfulde“ og ,de magtesløse“, men vel vidende, at det betyder, at det endnu en gang mislykkes for Ladan at forlade Grækenland, og at hun på den måde skal starte forfra? Vel vidende, at Ladan har faciliteret mit ophold i Grækenland, har åbnet sit midlertidige hjem og delt sin viden om livet en route med mig? Vel vidende, at folk som Ladan er desperate for at forlade Grækenland, fordi livet her er barskt og på mange måder er blevet til en kamp om daglig overlevelse, en kamp, ikke alle formår at komme igennem? Det er en ubarmhjertig situation, der tvinger antropologen til at foretage valg, valg, som afspejler vores adgange til og væren i felten, vores position(er) som antropolog, hvis formål er at producere viden, men på bekostning af hvem? Vores ansvar om ikke at gøre skade, men hvad er skadeligt og for hvem? Denne scene er ikke enestående. Tværtimod repræsenterer den de daglige valg, vi som antropologer foretager, ikke kun i vores egne felter, men i lige så høj grad med hinanden i kollaborative og komparative projekter.

\section{Perle tænker ...}

Hvad er det så, jeg føler, når jeg synes, jeg ikke bare kan fortælle Anja om de modaliteter, jeg har fået indsigt i ude i lufthavnen? Og er det overhovedet et „Perle-leak“"? Er det i virkeligheden ikke ting, som alle er ganske klar over? Ved både politi og migranter ikke udmærket, hvordan hinanden arbejder, og hvilke teknologier de disponerer over? Og omvendt, er de ikke lige meget i tvivl om, hvorvidt de er på forkant eller håbløst bagud i forhold til de andres taktikker? Er det ikke netop det, Johnna mener, når hun aldrig rigtig ved, om hun er katten eller musen? Hun ved, hvem hun og hendes kolleger af og til standser uden de rigtige papirer, men hun har intet overblik over alle dem, som de $i k k e$ får stoppet, kun en vag vished om, at der hele tiden slipper mennesker forbi dem, som udetekterede spøgelser. Når medarbejderne i Docuafsnittet, specialiseret i doku- 
mentfalsk, undersøger pas og id-kort med scanner og lup for at finde de små ting, som forfalskerne endnu ikke ved er blevet ændret i et bestemt id-kort, så er de hver gang ude på at se, om de stadig er på forkant - og afslører en falskner og en person, som har købt sig til det forfalskede id-kort - eller om de igen er blevet indhentet. Og hvis de er det, opdager de det netop ikke. Det er denne frustration over aldrig at vide, hvor effektiv man reelt er, hvor mange der er sluppet igennem nettet, og om ens strategier allerede er blevet afluret og omgået, som jeg synes, det er vigtigt at få indblik i, i praksis. Derudover undersøger jeg, hvordan grænsevagterne ser, både direkte og via forskellige teknologiske interfaces, såsom automatisk ansigtsgenkendelse og x-ray-scannere. Hvad ser de på, hvad ser de $i k k e$, og hvordan er deres selektive syn og øvrige sanser blevet formet professionelt? Og hvordan teknologiske, politiske, økonomiske og menneskelige mekanismer og konflikter spiller sammen i det daglige teknologisk understøttede filtreringsarbejde ved forskellige grænseovergange, har jeg fået indblik i ved at sidde med dér i det daglige arbejde. De informationer, jeg har fået om specifikke taktikker og personlige virkemidler, kan jeg måske ikke dele med Anja, af alle de nævnte grunde. Men objektet for os begge har heller ikke været de specifikke tegn, som bruges af den enkelte migrant og aflæses af den enkelte grænsevagt, og som jo konstant skifter, men snarere netop, hvordan de skifter og tilpasses hinandens nye taktikker. Og dér har vores samarbejde været yderst frugtbart. Selv om der er ting, som vi ikke kan dele med hinanden. Om fx sokker og bukser.

\section{Note}

1. Biometriske teknologier $($ bios $=$ liv, metron $=$ måle) bruges til at identificere mennesker ud fra specifikke kropslige kendetegn såsom fingeraftryk, iris, ansigtstræk, gangart osv. 